\title{
Streptococcus bovis Group
}

National Cancer Institute

\section{Source}

National Cancer Institute. Streptococcus bovis Group. NCI Thesaurus. Code C86785.

A bacterium that belongs to the Bovis group of the genus Streptococcus. 